\title{
Correction to: First report of fowl aviadenovirus serotypes FAdV-8b and FAdV-11 associated with inclusion body hepatitis in commercial broiler and broiler-breeder flocks in Turkey
}

İsmail Şahindokuyucu ${ }^{2}$ • Fethiye Çöven ${ }^{2} \cdot$ Hamza Kılıç $^{2}$ Özge Yılmaz ${ }^{2} \cdot$ Mustafa Kars $^{2} \cdot$ Öznur Yazıcıoğlu $^{2}$. Ercüment Ertunç ${ }^{2} \cdot$ Zafer Yazıcı $^{1}$

Published online: 27 November 2019

(c) Springer-Verlag GmbH Austria, part of Springer Nature 2019

Correction to: Archives of Virology

https://doi.org/10.1007/s00705-019-04449-w

The co-author names were found missed in the original publication of this article and the complete lists of authors were updated here. The original article has been corrected.

Publisher's Note Springer Nature remains neutral with regard to jurisdictional claims in published maps and institutional affiliations.

The original article can be found online at https://doi.org/10.1007/ s00705-019-04449-w.

İsmail Şahindokuyucu

ismail.sahindokuyucu@tarimorman.gov.tr

1 Veterinary Faculty, Ondokuz Mayıs University, Samsun, Turkey

2 Izmir/Bornova Veterinary Control Institute, Izmir, Turkey 